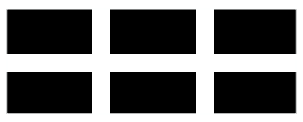

ThE WiLliam DAVIDSON INSTITUTE AT THE UNIVERSITY OF MICHIGAN BUSINESS SCHOOL

\title{
Ownership and Firm Performance after Large-Scale Privatization
}

\author{
By: Evzen Kocenda and Jan Svejnar
}

William Davidson Working Paper Number 471a

January 2003 


\title{
Ownership and Firm Performance after Large-Scale Privatization
}

\author{
Evzen Kocenda* \\ and \\ Jan Svejnar** \\ January 2003
}

\begin{abstract}
We analyze the effect of ownership on post-privatization performance in a virtually complete population of medium and large firms privatized in a model largescale privatization economy (Czech Republic). We find that concentrated foreign ownership improves economic performance, but domestic private ownership does not, relative to state ownership. Foreign firms engage in strategic restructuring by increasing profit and sales, while domestic firms reduce sales and labor cost without increasing profit. Ownership concentration is associated with superior performance, thus providing support to the agency theory and evidence against theories stressing the positive effects of managerial autonomy and initiative. Our results are also consistent with the thesis that the presence of a large domestic stockholder may not result in a superior performance if this shareholder "loots" the firm. We find support for a version of the hypothesis that firms restructure by first lowering and later increasing employment. The state as a holder of the golden share stimulates profitable restructuring while pursuing an employment objective, which is understandable in a period of rising unemployment. Our results hence portray the state as a more economically and socially beneficial agent than do some other recent studies.
\end{abstract}

Keywords: ownership, performance, privatization, panel data, industrial organization

JEL Classification: C33, D20, G32, G34, L20

* CERGE-EI, Prague; The William Davidson Institute at the University of Michigan Business School; CEPR

** The William Davidson Institute at the University of Michigan Business School and Department of Economics, University of Michigan; CERGE-EI, Prague; CEPR

We would like to thank Juraj Valachy for valuable computational assistance. We are indebted for valuable comments to Saul Estrin, Merritt Fox, Nandini Gupta, Jan Hanousek, Gábor Kezdi, Jan Kmenta, David Levine, Lubomír Lízal, Yingui Qian, Gérard Roland, and Klara Sabirianova. The paper also benefited from presentations at the 2003 Meetings of the American Economic Association, 2002 CEPR-WDI Conference on Transition Economics (Riga), 2002 LACEA Conference (Madrid), Michigan, and UC Berkeley. Kocenda holds Citibank Professorship at CERGE-EI, a joint workplace of Charles University and the Academy of Sciences of the Czech Republic. While preparing this paper, Svejnar benefited from ACE Grant No. P-981008-R and NSF Grant No. SBR-951-2001. 


\section{Introduction}

One of the fundamental and most controversial economic questions is whether private firms perform better than state-owned enterprises (SOEs) and whether privatization improves firm performance. There is now a large literature on the subject and the issue has gained currency as large-scale privatizations have taken place in many of the former command economies, former Yugoslavia and Latin America. The issue is also of interest because China and India are in the process of privatizing their state-owned firms.

Interestingly, while privatization is based on the premise that it will improve corporate performance and help countries grow, the effect has been surprisingly hard to identify. At the macro level, one observes that some of the fastest large-scale privatizers (e.g., Russia, Ukraine and the Czech Republic) experienced a decline or slow growth after privatization in the 1990s, while some of the fastest growing transition economies in the 1990s (e.g., China, Poland and Slovenia) were among the slowest to privatize. In a cross-country aggregate study, Sachs, Zinnes and Eilat (2000) find that privatization does not by itself increase GDP growth, but they suggest that a positive effect is present when privatization is accompanied by in-depth institutional reforms. Careful micro-econometric studies date back to Caves and Christensen's (1980) classic study that found the private and state-owned Canadian railways performing equally efficiently in a head-on competition. Recent surveys of privatization studies based on micro data come up with assessments that range from finding a large variation of outcomes but no systematically significant effect of privatization on performance (Bevan, Estrin and Schaffer, 1999), to cautiously concluding that privatization around the world improves firm performance 
(Megginson and Netter, 2001), to being fairly confident that privatization tends to improve performance (Shirley and Walsh, 2000, and Djankov and Murrell, 2002). ${ }^{1}$

In part, the variation in results is brought about by the fact that the early studies have access to different, and often very limited, data on firm ownership. ${ }^{2}$ For these reasons, most studies treat ownership as a relatively simple categorical concept (e.g., private v. state or state v. foreign, domestic private outsider v. domestic private insider), and they are often unable to distinguish the exact extent of ownership by individual owners or even relatively homogeneous groups of owners. As we discuss below, the inability to distinguish the extent of different forms of ownership also prevents many studies from providing evidence on a lively theoretical debate about the desirability of concentrated v. dispersed ownership on corporate performance. ${ }^{3}$

Equally important, the diversity of findings is generated by three types of interrelated analytical problems that may be expected in early studies, especially those in the context of the rapidly changing transition economies. First, the early studies rely on short time periods with observations concentrated immediately before and after privatization. ${ }^{4}$ They may hence at best capture the short-term effects of privatization, namely those associated with defensive (reactive) restructuring of firms, rather than the medium and long-term effects of a switch from state to a relatively stable form of private or mixed ownership. ${ }^{5}$ Second, the early studies (a) use small

\footnotetext{
${ }^{1}$ A theoretical analysis and overview of privatization and firm performance in transition is provided by Roland (2000).

${ }^{2}$ See for example Pohl, Anderson, Claessens, and Djankov (1997), Smith, Cin, and Vodopivec (1997), Claessens and Djankov (1999), and Frydman, Hessel, and Rapaczynski (2000).

${ }^{3}$ An important recent exception is Grossfeld and Tressel (2001).

${ }^{4}$ For example, Frydman, Gray, Hessel and Rapaczynski (1999) use a 1990-93 sample of about 200 firms pooled from the Czech Republic, Hungary and Poland; Barberis, Boycko, Shleifer, and Tsukanova (1996) use a sample of 260-340 Russian shops during the 1992-93 period; Bilsen and Konings (1998) use survey data for 1990-94 on about 260 firms divided among Bulgaria, Romania, and Hungary; Grosfeld and Nivet (1997) use a sample of 173 of the largest 500 companies in Poland during the 1988-1994 period; and Claessens and (1999) use data on approximately 700 manufacturing firms from the Czech Republic during 1993-97.

${ }^{5}$ See Grosfeld and Roland (1997) and Aghion and Carlin (1996) for discussions of the defensive and reactive restructuring.
} 
and unrepresentative samples of firms, (b) are often unable to identify accurately ownership because privatization was still ongoing or because the frequent postprivatization changes of ownership were hard to detect (Filer and Hanousek, 2002), and (c) often combine panel data from different accounting systems. As a result, the adequacy of data of the early studies is unclear. Third, many of the early studies have not been able to control adequately for selectivity (firms not being selected for privatization at random) and their estimates of the effects of privatization may hence be biased (Gupta, Ham and Svejnar, 2000). ${ }^{6}$

In this paper, we advance the literature by estimating the performance effects of key ownership patterns that we construct from detailed information on the extent of firm ownership by various owners. We exploit the fact that unlike other authors we know the identity of all firms in our data and have detailed information about their ownership and key indicators of performance. We are hence able to estimate the effects of ownership forms and degrees of ownership concentration that could not be examined before.

Moreover, we advance the literature by addressing systematically the three types of above-mentioned problems found in existing studies. In particular, we (a) use panel data on a virtually complete population of medium and large firms that went through large-scale privatization in a model economy (Czech Republic) and that constitute the bulk of the country's economic activity, ${ }^{7}$ (b) cover a four-year period after privatization when accounting rules conforming to the international (IAP)

\footnotetext{
${ }^{6}$ Gupta et al's. (2000) econometric evidence indicates that better performing firms tend to be privatized first.

${ }^{7}$ Since we use data on virtually the entire population of large and medium sized firms in the Czech Republic, one may think of our data as a country sample drawn from the population of centrally planned economies that went through large scale privatization. The Central European economies have served as models for other transition countries in that early on they carried out important reforms and policy makers from other countries and international institutions such as the World Bank and the International Monetary Fund have used them as examples to follow. In this context, the Czech
} 
standard were already in place, (c) control for selectivity, and (d) estimate the effects of ownership and changes in ownership after large-scale privatization. ${ }^{8}$

In addition, the fact that we use data from a model economy that started almost completely state-owned and within a short time span underwent large-scale privatization and large subsequent changes in ownership means that we are analyzing a population of firms that experienced one of the greatest recorded changes in ownership. Since a number of other countries, including Russia and Ukraine, started from almost complete state ownership and have carried out large-scale privatizations and subsequent changes in ownership, obtaining an understanding of the effects of this process and its aftermath is of considerable interest. Unlike studies of partial privatization, we also benefit from large variation in the variables whose effect we analyze.

Finally, by carrying out a detailed study on one model economy, we are able to take into account specific legal and institutional features that relate to ownership and control, and avoid the problem of not being able to control adequately for

Republic has served as the example of rapid, large scale privatization, while Hungary has been the example of piece-meal privatization of individual firms.

${ }^{8}$ The present paper belongs to a second generation of empirical studies that are being carried out to analyze corporate performance in the post-privatization period and employ large samples or populations of firm-level data from specific types of privatization in a given country. These studies are able to avoid some of the aforementioned problems and take into account specific institutional settings. Thus, Bornstein (2001) for instance examines the post-privatization restructuring of former SOEs, including examples from the Czech Republic, Hungary and Poland. Angelucci, Estrin, Konings and Zólkiewski (2001) use a large representative panel of manufacturing firms covering the years 1997-98 for Bulgaria and Romania, and 1994 and 1998 for Poland. Carlin, Fries, Schaffer and Seabright (2002) employ an EBRD survey of 3,300 firms in 25 transition countries to identify factors that influence restructuring by firms and their subsequent performance as measured by growth in sales and in sales per employee over a 1996-1998 period. Lizal and Svejnar (2002) use a 1992-98 panel data on the population of medium and large Czech industrial firms to examine investment behavior and the extent of credit rationing and soft budget constraints by ownership and corporate form of firms. Our paper has the advantage of being based on more complete and detailed data on ownership and performance than other studies. We also develop a more systematic analytical framework that allows us to evaluate the performance effect of initial post-privatization ownership as well as to distinguish between instantaneous and permanent effects of ownership changes. Finally, unlike other studies, we estimate the principal effects in both linear and nonlinear form. 
complex cross-country differences in the institutional and legal frameworks that confront comparative studies with limited number of country-specific observations. ${ }^{9}$

The structure of the paper is as follows. In Section 2, we provide information on the privatization process that generates our data, while in Section 3 we discuss the relevant features of the legal system and the hypothesized implications of different types of ownership on firm performance. In Section 4, we describe the data and basic statistics and in Section 5 we outline our empirical strategy. We present our empirical estimates in Section 6 and we draw conclusions in Section 7.

\section{Privatization in the Czech Republic}

The privatization program in the Czech Republic was carried out in the first half of the 1990s under three different schemes: restitution, small-scale privatization and large-scale privatization. The first two schemes started in 1990 and were most important during the early years of the transition. Large-scale privatization, by far the most important scheme, began in 1991 and was completed in early $1995 .{ }^{10}$ The privatization program allowed various privatization techniques. Small firms were usually auctioned or sold in tenders. Many medium businesses were sold in tenders or to pre-determined buyers in direct sales. Most large and many medium firms were transformed into joint stock companies and their shares were distributed within voucher privatization (almost one-half of the total number of all shares of all joint stock companies was privatized in the voucher scheme), sold in public auctions or to strategic partners, or transferred to municipalities.

\footnotetext{
${ }^{9}$ In one of the leading studies in this area, Frydman et al. (1999) are for instance forced by paucity of data to use pooled cross-country regressions from the Czech Republic, Hungary and Poland to derive their key findings.

${ }^{10}$ The privatization process has been extensively described and analyzed. See e.g., Svejnar and Singer (1994), Kotrba (1995), Coffee (1996), and Kočenda (1999).
} 
The voucher scheme was part of the large-scale privatization process and it attracted considerable interest and publicity. ${ }^{11}$ Two waves of voucher privatization took place in 1992-93 and 1993-94, respectively. The early post-privatization ownership structure emerged as shares from the second wave were distributed in early 1995. Rapid reallocation of shares across new owners took place in 1995-96 during the so-called "third wave" of privatization as new owners, including the investment privatization funds (IPFs), reshaped their initial post-privatization portfolios of acquired companies. Depending on the investor, the swapping of shares in 1995-96 was aimed at (a) optimal portfolio diversification, (b) obtaining concentrated ownership in specific firms and industries and (c) achieving conformity with legal requirements aimed at preventing excessive stakes being held by privatization funds. ${ }^{12}$

The 1995-96 ownership changes were massive, unregulated and frequently unobservable to outsiders, including researchers. Investors, especially the IPFs, engaged in direct swaps of large blocs of shares and off-market share trading was common. More stable and, from the standpoint of firm performance, more meaningful patterns of ownership emerged in 1996. We analyze the 1996-99 performance effects of various patterns of ownership and their changes after the dust of large-scale privatization and early post-privatization ownership swaps settled.

\section{Forms of Ownership and Hypothesized Effects on Performance}

\section{Concentrated or Dispersed Ownership?}

\footnotetext{
${ }^{11}$ The voucher scheme is sometimes erroneously referred to as the large-scale privatization program.

${ }^{12}$ The regulation of IPFs evolved gradually through Decree no. 383/1991, its Amendment No. 62/1992, and Act No. 248/1992. The most important clauses restricted each privatization fund from investing more than $10 \%$ of points acquired in the voucher scheme in a single company and obtaining in exchange more than $20 \%$ of shares in any company. Privatization funds established by a single founder were allowed to accumulate up to $40 \%$ shares in a given company but this cap was later reduced to $20 \%$. Many privatization funds circumvented the cap through mergers. The Act also prohibited IPFs founded by financial institutions from purchasing shares of other financial institutions to prevent excessive concentration of financial capital (for details see Kotrba and Svejnar, 1994).
} 
The link between firm performance and ownership is often viewed as going through the interaction and power distribution between the owners and managers of firms. In this context, the issue that has received major renewed attention, without resulting in a consensus, is whether concentrated or dispersed ownership is more conducive to good corporate governance and performance. The literature that focuses on the agency problem arising from the separation of ownership and control usually argues for the desirability of concentrated ownership since it results in better monitoring of managers, maximization of shareholder value and availability of external finance for the firms (see e.g., a survey by Shleifer and Vishny, 1997). As Burkart, Gromb and Panunzi (2000) have shown, this effect may exist even when a large (minority) stockholder is present -- if this shareholder loots the firm at the expense of small shareholders. On the other hand, models that stress the importance of managerial initiative and incentives to acquire information (e.g., in situations of high uncertainty) conclude that concentrated ownership may be deleterious to firm performance (see e.g., Aghion and Tirole, 1997). Dispersed ownership also results in greater liquidity of the company's stock, which is viewed by some as improving the information value of the stock market and therefore enhancing the performance of firms (e.g., Holmstrom and Tirole, 1983). Finally, ownership dispersion is viewed as being optimal, provided it can give rise to controlling stakes when managerial decisions need to be blocked and/or restructuring needs to be carried out (Bolton and von Thadden, 1998).

Since we are able to identify all owners with ownership stakes of 10 percent or more, we can classify all firms into categories that allow us to test the validity of the competing predictions from the above theories. Depending on their stakes, different blockholders have different capacity to influence corporate governance. In particular, 
the Czech law provides important rights of ownership and control to owners with majority ownership (more than 50 percent of shares), blocking minority ownership (more than 33 percent but not more than 50 percent of shares) and what we define as legal minority ownership (at least 10 but not more than 33 percent of shares). ${ }^{13}$ Majority ownership grants the owner the right to staff management and supervisory boards, to alter and/or transfer firms' assets and to adopt most crucial strategic decisions at general shareholders' meeting. Through management and supervisory boards, majority ownership allows also more direct executive control over the company. The blocking minority ownership gives the right to block a number of decisions, such as those related to increasing or reducing assets and implementing major changes in business activities that the majority shareholder may strive to implement at the general shareholders' meeting. Finally, legal minority ownership can be considered a form of dispersed ownership since its concentration is low and its direct impact on routine business decisions is limited. On the other hand, it is potentially important since the law entitles the holder of such a stake to call the general shareholders' meeting and obstruct its decisions by delaying their implementation through lengthy court proceedings. Effective legal minority shareholders (including the state) may thus use their ownership position to delay or completely block the implementation of decisions by stronger shareholder(s). ${ }^{14}$

\footnotetext{
${ }^{13}$ In principle, we cannot fully trace ownership stakes of less than 10 percent since their reporting is not required by law. This limitation is not particularly constraining for our analysis for two reasons. First, by having data on all owners with 10 percent or more ownership, we are able to estimate the effects of the most relevant degrees of concentration and dispersion of ownership, ranging from a single owner having majority ownership, to no single owner having the legal (10 percent) minority ownership. Second, as we discuss below, we are able to trace even ownership stakes of less than 10 percent in firms that are of particular analytical interest to us.

${ }^{14}$ Another effect is observed in the case of portfolio companies that are primarily interested in capital gains. These companies have been observed to buy 10 percent positions in firms where they can sell the stake at a premium to the dominant shareholder whose business strategy is to avoid excessive scrutiny by an institutionally strong minority shareholder.
} 
Overall, majority and blocking minority represent different degrees of concentrated ownership, while legal minority may be viewed as a form of moderately dispersed ownership. Highly dispersed ownership arises when the stake of the largest holder held does not reach legal (10 percent) minority. We are also able to distinguish whether the government keeps a golden share that gives it the right to veto certain managerial decisions, such as the subject of business activities, termination of provided services, sales of assets, etc. and indirectly to influence all managerial decisions. Institutional evidence suggests that the golden share may be an important mechanism enabling the state to exert a degree of influence over firms in which it no longer holds a sufficient ownership stake. ${ }^{15}$

\section{Types of Ownership}

Most empirical work has focused on relatively broad categories of ownership such as government versus private, domestic versus foreign and insiders (managers and workers) versus outsiders. While useful as a first-order approximation, it is desirable to assess if finer distinctions that reflect the business activities of owners provide a clearer understanding of the effects of different types of ownership and corporate governance. In our analysis, we take a step in this direction by examining six types of domestic and two types of foreign ownership that are likely to have differing implications for corporate objectives, constraints and governance.

The six types of domestic owners are industrial company, bank, investment fund, individual, portfolio company, and state, while the two types of foreign owners

\footnotetext{
${ }^{15}$ The golden share was introduced by Act No. 210/1993, modifying Act No. 92/1991. The act set the conditions for property transfer from the state to others with the aim of protecting special interests of the state in firms privatized in large privatization. The veto rights associated with the golden share usually relate to the scope and line of business activity and depend on each company's charter. When the state sells its golden share, it gives up its rights in the company and the golden share cease to exist. The instrument of golden share in the Czech Republic does not conform fully to that found in other countries since it is limited to being solely an instrument of state control and does not serve as means of attracting free or less expensive credit.
} 
are industrial company and all other owners. ${ }^{16}$ The ownership of a firm by an industrial company is normally expected to increase profitability through cost cutting, vertical or horizontal integration of activities, and possibly expansion aimed at exploiting economies of scale. However, in the incomplete legal and institutional framework of the transition, one might observe an opposite effects if the parent company's management appropriates the acquired company's profits and/or assets (i.e., tunnels) or if it uses the company for tax evasion or other private purposes.

A significant bank ownership or credit exposure to a firm should impose pressure on the firm's management to improve profitability (Cornelli, Portes, and Schaffer, 1996). However, the newly-created banks found themselves holding large credit and ownership positions in hundreds of firms and had only limited ability to staff the firms' management and supervisory boards with capable individuals. ${ }^{17}$ Moreover, the banks' ownership role was weakened by their lending relationship with the firms they owned and by laws and a regulations that limited their authority and tolerated corruption (see Lízal and Kočenda, 2001). The effect of bank ownership on performance is hence an empirical question.

Investment funds were created during large-scale privatization as diversified mutual funds. They are expected to pursue profitable opportunities, which may in the medium term translate into emphasis on sound corporate governance of firms. In the short term, however, the funds may focus on increasing the value of the stocks held in their portfolios by strategic trading rather than by pursuing issues of corporate

\footnotetext{
${ }^{16}$ Since insiders have not been important in the Czech Republic, we do not analyze this type of ownership. We also do not examine whether a given owner belongs to a larger ownership group. With considerable additional data work, this could be an interesting topic for future research. To study crossownership patterns and their effects is, however, beyond the scope of this paper.

${ }^{17}$ Ownership involvement of Czech banks in other companies resembles the situation in Germany. Allen and Gale (1995), with reference to German financial market, argue that the fact that the market for corporate control collapses when stock markets are thin could be made up for by the role of banks as delegated monitors holding equity and exercising their voting rights. Czech banks with their
} 
governance at the level of individual firms. ${ }^{18}$ Moreover, a number of observers have pointed out that the corporate governance of many of the funds themselves has been weak (e.g., Iskander and Chamlou, 2000, p.75). Thus, the fund managers could use controlling ownership stakes to extract benefits from the company at the expense of minority shareholders, and enrich themselves at the expense of fund depositors. ${ }^{19}$

Individual ownership is widely perceived as an ideal form of corporate governance with the residual claimant having very strong incentives to monitor the management. The impact of these incentives should become even stronger when the individual owner is part of management.

The portfolio companies in the Czech Republic are investment companies that engage in doing business with both corporate and private customers. Their ownership positions in firms reflect their goal of realizing financial gains of their clients. Thus, they have tended to pursue short-term capital gains and they normally have not participated in corporate governance. While the experience in advanced market economies indicates that portfolio companies owning significant stakes often force management to become more profitable, it is not clear that this aspect of performance would be found in the post privatization period.

The state, as an owner, may pursue various goals, including economic efficiency, tax revenues, or social goals such as employment. The results of Gupta et al. (2000) suggest that revenue maximization was important in the privatization phase, but other goals, such as employment generation, may be important in the post privatization phase when unemployment went up.

numerous holdings were given the above option, however, their ability to cope with it might not be strong.

${ }^{18}$ Jensen (2000, p.220) for instance argues that mutual funds tend to survive when they hold securities of firms that trade at low valuations in secondary markets.

${ }^{19}$ The famous tunneling (looting) of firms by some investment funds that occurred during large scale privatization is reported to have been less of a phenomenon by 1996 . 
Finally, in a country with favorable profit repatriation rules, foreign owners are likely to aim at generating profits and, if the local products can be sold through the worldwide network, also on increasing output and hence employment.

\section{The Data and Basic Statistics}

Profitability is widely viewed as the best ultimate measure of corporate performance and we use the rate of change of operating profit as one of our dependent variables. However, since even small absolute changes in profit near the zero profit level may yield enormous values of the rate of change, we also use change in the return on assets (ROA), proxied by the ratio of the change in operating profit between periods $\mathrm{t}-1$ and $\mathrm{t}$ to total assets in period $\mathrm{t}-1$. Moreover, in order to provide an understanding of whether corporate restructuring proceeds more on the revenue or cost side (the two main components of profit), we use the rate of change in sales revenue and labor cost as two additional indicators of performance. ${ }^{20}$

Our working data set contains 2,529-2,949 observations on an unbalanced panel of 1,371-1,540 medium and large firms from all economic sectors. As we indicate in Table 1, the exact number of observations and firms varies across the four performance indicators. The observations represent a cleaned data set from the entire population of firms that were either listed on the Prague Stock Exchange (PSE) throughout the 1996-1999 period or that started to be traded on the PSE sometime during 1996-1999 and were later de-listed. De-listing did not eliminate firms from the sample and the sample size therefore does not diminish over time. ${ }^{21}$ Since virtually all large and medium-sized firms privatized in large scale privatization were listed on

\footnotetext{
${ }^{20}$ We do not use other measures of performance because the sample size would be substantially reduced due to limited data availability.

${ }^{21}$ In future research, it will be of interest to examine the relationship between de-listing, firm type and performance.
} 
PSE, the data set contains most of these firms. In addition to performance variables, the data set contains detailed measures of ownership structure, sector in which the firm operates, and the firm's privatization history. The data sample was compiled by the authors from information provided by Aspekt, a commercial database, The Prague Stock Exchange, The National Property Fund of the Czech Republic, and the Business Register of the Czech Republic. ${ }^{22}$

As is known from empirical studies on transition and emerging market economies, firm-level data often suffer from accounting deficiencies and they usually contain missing values and outlier observations that may bias the estimated coefficients (e.g., Filer and Hanousek, 2002). Firms operating in the Czech Republic started adopting international accounting (IAP) standards in 1992 and our discussions with international accounting firms located in the country indicate that this process was by and large completed in 1995. Our 1996-99 data are hence from a period in which IAP already dominated local accounting standards. Moreover, the data are reported by firms that had to conform to the standards demanded in the second half of the 1990s by the main regulatory institutions, namely the Prague Stock Exchange, The National Property Fund (the privatization agency) of the Czech Republic and the Czech National Bank. The data are hence relatively reliable and free from the accounting deficiencies that plague earlier studies.

We have adopted a three-step approach to handling missing observations and outliers in the original data set of $3040,3050,2648$, and 2972, year-to-year rate of change observations for profit, ROA, sales, and labor costs, respectively. First, we eliminated the few (rate of change) observations that were based on inconsistent values in the levels of variables, such as negative values of sales or labor cost. This

\footnotetext{
${ }^{22}$ The data set does not contain information on the pre-1996 period.
} 
resulted in 3040, 3050, 2644, and 2972 observations for the rate of change of profit, ROA, sales, and labor cost, respectively.

Second, since the data still contained a number of observations with fairly extreme values, we examined the sensitivity of parameter estimates to the trimming of these extreme values of variables, identifying points where the results became relatively insensitive to further trimming. We found that the estimates ceased being sensitive to trimming at the point where the year-to-year rate of change in the performance indicators was constrained to the wide interval of $(-300 \%, 300 \%)$ for profit, $(-40 \%, 40 \%)$ for ROA and $(-100 \%, 300 \%)$ for sales and labor costs. ${ }^{23}$ Imposing these wide limits led to a relatively modest reduction in the number of observations and resulted in 2529 observations for the rates of change in profit, 2905 for ROA, 2592 for sales, and 2949 for labor cost. We have used Heckman's (1979) procedure to correct for the possible sample selection bias brought about by the two-step data cleaning procedure. ${ }^{24}$

Third, we explored the possibility of creating a balanced data set with the same firm-year pairs across the four performance indicators. We found that this would require reducing the number of observations for the rate of change of profit, ROA, sales, and labor costs by 403 (16\%), 779 (27\%), $466(18 \%)$, and $823(28 \%)$, respectively, resulting in a sample with only 1272 firms and 2126 observations. We have considered this further reduction in the number of observations to be excessively large. We have hence used the larger sample from step two above, but we have also generated Heckman-corrected estimates based on the balanced sub-sample for

\footnotetext{
${ }^{23}$ In contrast, the estimated coefficients change dramatically and non-monotonically as we add the outlying observations beyond this borderline to the sample.

${ }^{24}$ In particular, using the original set of observations we first ran a Heckman-type probit equation, predicting the probability that a given observation is included in the subsample on the basis of the following variables: the initial values of the performance indicators and their squares and products, as well as dummy variables capturing the presence of a given firm in a particular privatization wave.
} 
comparison (not reported here). The findings based on the balanced sub-sample are broadly similar to those based on the larger sample.

On average, within the four-year (1996-99) period we have data for three consecutive years to compute annual rates of change of performance variables (Table $1) .^{25}$ In terms of the number of firms and observations, our sample is larger than samples used in previous and most ongoing studies in this area. More detailed summary statistics of performance indicators by ownership type and ownership extent are presented in appendix tables A1 and A2. We have also carried out a number of checks against official and private records to verify that our ownership information is reliable and that we hence meet the criticism of earlier privatization studies raised by Filer and Hanousek (2002).

As may be seen in Table 2, domestic industrial companies are the most frequent single largest owners (SLOs) with 1, 244 observations, followed by domestic investment funds (423 observations), domestic individuals (335) and the Czech state (174). Foreign industrial companies are by far the most frequent SLOs among the foreign investors (236 observations), and the total number of foreign SLO observations is 303 . Ownership concentration, measured by the average stake held by a SLO, is between 38 and 59 percent, which is rather high in comparison to ownership concentration in developed countries (Demsetz and Lehn, 1985) and it resembles more the continental European than Anglo-American ownership concentration patterns. $^{26}$

Foreign owners as a group tend to hold majority ownership stakes in firms (panel B of Table 2). The situation is just the opposite for domestic private owners

\footnotetext{
${ }^{25}$ There are 34 sales and 28 labor cost observations for which the rate of growth is equal to -1 . This means that only a limited number of firms in our sample ended production during the analyzed period. ${ }^{26}$ For development of ownership structures in voucher-privatized firms see Kočenda and Valachy (2002).
} 
and the state, both of which have average stakes around 43-45 percent and display absolutely and relatively more cases of blocking and legal minority ownership than majority ownership. Moreover, the state retains a golden share primarily in firms in which it or domestic private owners are the SLO. Finally, there are 33 observations with highly dispersed ownership in the sense that no type of owner has even a legal (10 percent) minority ownership. These observations come from 25 firms that are larger than average in terms of total assets, but otherwise tend to have quite diverse characteristics. $^{27}$

In panels $\mathrm{A}$ and $\mathrm{B}$ of Table 3, we present two transition matrices depicting the 1996-99 changes in firm ownership by extent and type of ownership, respectively. The flows by the extent of state, domestic private and foreign ownership (Panel A) show that majority foreign and majority domestic ownership forms are stable in that 73 percent and 68 percent of firms that were in these two categories in 1996, respectively, were in the same categories also in 1999. Together with the category of blocking minority domestic firms, these two categories are also the main ownership forms to which firms switched from other categories, especially from blocking and legal minority state ownership, legal minority foreign ownership and neither majority nor minority ownership. When measured by the type of SLO (Panel B), domestic and foreign industrial companies are the stable forms, retaining respectively 69 and 75 percent of their 1996 firms in 1999. Together with the domestic investment funds and individually owned companies, these two ownership forms are also the main recipients of firms from other categories, especially domestic portfolio companies and banks and foreign other (non-industrial) firms. Overall, there was hence a substantial

\footnotetext{
${ }^{27}$ The firms belong to various sectors, with 7 being in trade and 4 in constructions and building materials sectors. In 5 firms foreign owners have largest, albeit relatively small, stakes. The state holds golden share in two of these firms, both of which are water supply utilities.
} 
amount of ownership changes even during the relatively stable, post-privatization period under study. In terms of the categories in Table 3, 15 to 31 percent of our sample changed category by extent of ownership and 7 to 48 percent by type of SLO, with the greatest (smallest) shift being toward an industrial company (bank) as the SLO. The ownership changes were relatively evenly distributed over the 1996-99 period, with no single year showing unusually pronounced shifts.

\section{The Econometric Model}

Our main goal is to analyze the post-privatization performance effects of the principal types of ownership that were established during large-scale privatization (1992-95) and immediately thereafter (1995-96). In addition, we want to control for and estimate the effects of the substantial changes in ownership that took place in the 1996-99 post-privatization period that we analyze. In order to carry out this analysis, we adapt the Ashenfelter and Card (1985) and Heckman and Hotz (1989) panel data treatment evaluation procedure for this context.

Let $X_{i j t}$ be a given performance indicator, with subscript $i$ denoting individual firm under ownership type $j$, in year $t$, and let $y_{i j t}$ be the percentage change of $X_{i j t}$ from $t-1$ to $t$. Moreover, let $P_{i j t}$ denote ownership type $j$ of firm $i$ in year $t$ and $D_{t}$ be a vector of annual and industry/sector dummies, and dummy variables indicating whether the firm was privatized in the first or second wave of the voucher scheme or outside of it. We estimate a model that captures the annual rate of change of performance:

$$
y_{i j t}=\alpha+P_{i j 1} \beta_{j}+X_{i j 1} \gamma_{j}+\Delta P_{i j \tau} \delta_{j}+P_{i j \tau} \phi_{j}+D_{t} \varphi+\varepsilon_{i j t}
$$

where $\alpha$ represents the base effect of state ownership, column vector $\beta_{j}$ captures the effects of other types of initial post-privatization ownership $P_{i j 1}$ that are measured 
relative to the base effect of state ownership, vector $\gamma_{j}$ controls for the effect of initial post-privatization level of performance $X_{i j l}$ on future rate of change of performance, vector $\delta_{j}$ captures the contemporaneous (instantaneous) effect observed in any year $\tau$ after 1996 if a firm changed its 1996 ownership to a new ownership category -$\Delta P_{i j \tau}$, vector $\phi_{j}$ reflects the permanent effect associated with a new type of ownership $P_{i j \tau}$ established at time $\tau$ after large-scale privatization, and vector $\varphi$ represents the effect of the annual, industry and form of privatization dummy variables. Coding the dummy variables so that the effects of non-state ownership forms is measured relative to the effect of state ownership is conceptually appealing since firms in which the state retains ownership and control are the least privatized and on average probably also the least transformed ones. The approach also accords with our desire to investigate change in performance as firms switch from state to private ownership.

Our specification in equation (1) controls for the effects on the rate of change of performance of inter-firm differences in the initial post-privatization performance measured by profitability, revenues and labor cost, respectively. It also controls for industry-specific fixed effects (proxying for factors such as the degree of competition or differences in technology), annual economy-wide shifts (such as macro shocks or degree of openness to trade), and fixed differences among firms that were or were not part of the voucher scheme. As we discuss below, these variables also control for potential selectivity as firms with different performance potential may have been channeled to different parts of the privatization program, which in turn may have affected their initial performance after privatization. Finally, in equation (1) we control for possible selectivity problems associated with changes in ownership in the 1996-99 period by including ownership group fixed effects $\delta_{j}$ for firms undergoing 
these ownership changes. ${ }^{28}$ These $\delta_{j}$ effects may also reflect instantaneous changes in performance associated with the new ownership.

Equation (1) may be viewed as coming from a framework such as that invoked in the endogenous growth literature (e.g. Temple, 1999, Barro and Sala-i-Martin, 1995), where the rate of change of the dependent variable may depend on its initial level (e.g., rate of change of performance being related to an initial level of investment) and some other variables. Alternatively, the equation may be thought of as constituting the first difference of a logarithmic model of performance:

$$
\ln X_{i j t}=\alpha_{i}+\alpha t+\left(P_{i j 1} t\right) \beta_{j}+\left(X_{i j 1} t\right) \gamma_{j}+P_{i j \tau} \delta_{j}+\left[P_{i j \tau}(t-\tau)\right] \phi_{j}+D_{t}^{\prime} \varphi+v_{i j t}
$$

where $\alpha_{i}$ controls for firm-specific (fixed effect) differences in performance across firms after large-scale privatization, $D_{t}=D_{t}^{\prime}-D_{t-1}^{\prime}$ and $\varepsilon_{i j t}=v_{i j t}-v_{i j t-1 .}{ }^{29}$ Thus, equation (1) represents an approximation of the first difference of equation (2). ${ }^{30}$

An important issue that arises in the context of post-privatization behavior of firms is the dynamics of their restructuring and performance. The performance effect of short-term (defensive or reactive) restructuring is for instance often hypothesized to differ from the medium-term (strategic) restructuring associated with different forms of ownership (e.g., Blanchard, 1997, Roland, 2000, and Carlin et al., 2001).

\footnotetext{
${ }^{28}$ Analogously to including $X_{i j l}$ as a regressor, we have also estimated models controlling for $X_{i j \tau}$, the effect of performance achieved by the previous owner at the time of change of ownership $\tau$ on future performance. This specification did not produce materially different results from those of equation (1). ${ }^{29}$ An analogous approach, focusing on firm performance immediately before and immediately after privatization, was employed by Frydman et al. (1999). In particular, Frydman et al. (1999) used the Ashenfelter and Card (1985) and Heckman and Hotz (1989) approach to estimate an ownership-group fixed effects model of the form $y_{i j t}=\alpha_{j}+P_{j i t} \beta_{j}+X_{i j t-1} \gamma+D_{c t} \delta_{c t}+\varepsilon_{i j t}$, where $D_{c t}$ denoted a vector of annual country and dummy variables, as well as a firm-specific fixed-effects model: $y_{i j t}=\alpha_{i}+P_{i j t} \beta_{j}+D_{c t} \delta_{c t}+\varepsilon_{i j t}$. The estimates from these two models are unfortunately not directly comparable since the latter model omits $X_{i j t-1}$ and is hence not a direct extension of the former one.

${ }^{30}$ In the context of the debate about the performance effects of ownership vs. competition, we therefore focus on the effects of ownership, while controlling for the extent of competition by the firm-specific fixed effects, the effect of initial performance interacted with the time trend, and the industry-specific and annual time dummy variables interacted with time.
} 
Moreover, strategic restructuring may take time to carry out and it may hence have a performance effect that varies over time. Blanchard (1997) has for example hypothesized that the effect of privatization would tend to have a U-shaped effect on employment and we conjecture that there may be non-linear effects on other dependent variables as well. We hence also estimate a model that allows the performance effects of the various ownership forms to vary linearly and quadratically with time, where time is measured as the number of years since 1996 and since any subsequent change of ownership at time $\tau^{31}$

$$
\begin{aligned}
y_{i j t}= & \alpha+\alpha^{\prime} t+\alpha^{\prime \prime} t^{2}+P_{i j 1} \beta_{j}+\left(P_{i j 1} t\right) \beta_{j}^{\prime}+\left(P_{i j 1} t^{2}\right) \beta_{j}^{\prime \prime}+X_{i j 1} \gamma_{j}+\Delta P_{i j \tau} \delta_{j}+ \\
& +P_{i j \tau} \phi_{j}+\left[P_{i j \tau}(t-\tau)\right] \phi_{j}^{\prime}+\left[P_{i j \tau}(t-\tau)^{2}\right] \phi_{j}^{\prime \prime}+\delta D_{t}+\varepsilon_{i j t}
\end{aligned}
$$

An interesting feature of our data is that we are able to explore the effect of ownership forms in two key directions. First, we can examine whether majority, blocking minority and legal minority ownership of a particular type affects the firm's post-privatization performance. We can also assess if the state can affect performance by retaining a golden share that gives it the right to block certain managerial decisions. Second, we can evaluate the performance effects associated with different types of single largest owners, and whether the SLOs have a majority, blocking minority, or legal minority stake. The ability to distinguish these ownership forms enables us to provide evidence with respect to the key issues discussed earlier.

\section{Extent of Ownership}

As we discussed in Section 3, the analysis of the effect of majority and blocking minority ownership is important because these categories of ownership are widely believed to have major effects on corporate governance and performance of firms. Assessing the effect of legal minority is also important because it is an easier

\footnotetext{
${ }^{31}$ Since the time period is short, we use this second order Taylor series approximation for the
} 
ownership stake to obtain and it gives the owner legal rights that enable him to influence corporate governance and performance.

Since the relative performance of state, domestic private and foreign ownership is one of the major issues in the privatization debate, we first focus our analysis on these three categories of ownership. In particular, we allow corporate performance to depend on whether private domestic owners as a group, foreign owners as a group, or the state have a majority, blocking minority or legal minority share ownership in the firm, and we also account for the effect of the state retaining a golden share.

\section{The Single Largest Owner}

In the above analysis of extent of ownership, we focus on the effects of majority and blocking or legal minority ownership, irrespective of how many different owners comprise the majority or minority groups. Highly concentrated and widely dispersed ownership within a given group is hence assumed to have the same effect on performance, a feature that may be too restrictive in view of the aforementioned theoretical controversy in this area. In the second prong of our analysis, we therefore focus on the effects of the single largest owner (SLO) and we exploit the fact that our data permit us to distinguish among eight different types of SLOs as well as the extent of their ownership.

As mentioned earlier, since the firms in our sample may display systematic heterogeneity because they were privatized in the large-scale privatization program, both within and outside the voucher scheme that occurred in two waves, and because Gupta et al. (2000) found that better performing firms tended to be privatized in the first wave. Moreover, firms privatized earlier have a longer post-privatization period before we observe them in our data in 1996. To control for the potential selectivity

underlying nonlinear form. 
bias stemming from these phenomena, we have included as regressors in the rates of change equations dummy variables indicating whether the firm was privatized in the first or second wave of the voucher scheme or outside of it (within large-scale privatization in general), the level of performance of the firm after large-scale privatization in 1996, and industry/sector and annual dummy variables (vector $D$ ). ${ }^{32}$ We have also employed the Kruskal-Wallis (1952) test to check for differences in the 1996-99 variation of the performance variables of firms from the first and second wave of the voucher scheme, as well as the difference in each of these sets of firms and those privatized outside of the voucher scheme. The test does not find the variation in the growth rates of variables for the three sub-samples to be different from one another.

Finally, in terms of the method of estimation, we report estimates that are generated by the Huber (1967)--White (1982) procedure to provide heteroskedasticity adjusted residuals. As mentioned in the data section above, we have also employed Heckman's (1979) procedure to correct for possible selection bias associated with the elimination of outliers. Finally, we have checked that the residuals are free from serial correlation.

\section{Empirical Results}

Our empirical strategy is to start from the broad model that incorporates the time-varying effects (equation (3)) and test restrictions implying that the effect of ownership on the performance indicators is constant over time (equation (1)). In particular, for each type of ownership we first test whether the coefficients on the

\footnotetext{
${ }^{32}$ When expressed as a model of the determinants of the level of firm performance, along the lines of equation (3), it is clear that the present specification controls for firm-specific fixed effects and allows the above dummy variables and the 1996 performance variable to control for systematic linear differences in post-privatization performance over time.
} 
ownership dummy variable and its linear and quadratic interaction with time are jointly statistically significant. When the F-test indicates that the three coefficients are jointly significant, we test whether the two coefficients on ownership interacted with time and with time squared are jointly significant. If this hypothesis cannot be rejected, we report the mean effect of the given ownership, calculated from the three estimated coefficients and from the mean values of the three variables. Next to the reported coefficients, we also indicate whether the underlying effect is convex, or Ushaped $(U)$, or concave, inverted U-shaped $(\cap)$, with time. When the three coefficients are jointly not significant or when they are significant but the effect of the linear and quadratic interaction of ownership with time is insignificant, we report the coefficient on the ownership dummy variable from a specification that constrains the coefficients on the linear and quadratic terms in time to be zero. In order to make the estimates easily interpretable, we report the associated p-values from the relevant Ftest or t-test in parentheses.

In Tables 4 and 5, we present the estimated effects given by equations (1) or (3), whichever is selected by the aforementioned tests. We start with the performance effects of the extent of ownership in Table 4 and then proceed with effects of particular types of owner in Table 5.

\section{Effects of the Extent of State, Private and Foreign Ownership}

In Table 4, each performance variable is related to whether domestic private owners, foreign owners or the state have a majority, blocking minority, legal minority, or less than legal minority ownership, and whether the state keeps a golden share in the firm. The constant reflects the 1996-97 rate of change in performance of firms that have majority state ownership, were partially privatized outside of the voucher scheme, and operate in the miscellaneous ("other") category of the 19 industries for 
which we control. The estimated coefficients on the various forms of ownership represent the average annual ownership effects relative to the above effect of majority state ownership. $^{33}$

As may be seen from Table 4, the extent of initial (1996) post-privatization forms of ownership has different effects on the return on assets (ROA) and operating profit. ROA is affected positively by majority foreign ownership and negatively (to a lesser extent) by legal minority foreign ownership. No other form of initial postprivatization ownership has an effect that differs from the base given by state majority ownership. Results for the rate of change of operating profit show that majority and blocking minority domestic private and majority foreign ownerships, as well as legal minority domestic and highly dispersed ownerships, register large positive effects, relative to majority state ownership. The two sets of results are sobering because they imply that only majority foreign ownership is conducive to profit-generating restructuring at profit levels that are substantially different from zero, while domestic private ownership does not increase ROA over and above that achieved by majority state-owned firms. With respect to foreign ownership, the results support the agency theory prediction that concentrated ownership improves performance and contradict theories claiming that dispersed private ownership, giving autonomy to managers, is

\footnotetext{
${ }^{33}$ Since our specification employs industry and annual dummy variables, and uses state majority ownership as part of the base that makes up the regression constant, it provides a convenient way to measure the average effects (across years and industries) of various forms of ownership, relative to the majority ownership by state. However, the specification does not lend itself to expressing in a simple way the average effect of state majority ownership since this effect varies across industries and years. To provide the reader with an estimate of the average effect of state majority ownership, we have therefore also estimated a more parsimonious model in which state majority ownership forms the constant and in which there are no annual, industry and privatization form dummy variables. In this model, the constant provides an estimate of the average effect of state majority ownership (available upon request). These estimates show that the state as a majority owner is associated with a 4.8 annual percentage point growth of labor cost and a 1.7 decline in ROA. It does not engender a significant change in operating profit and sales. When the state is in a blocking or legal minority position in a firm, it does not bring about any significant change in performance measures. The state is also associated with an additional 1.7, 8.0, 5.1 and 5.3 percentage point increase in ROA, operating profit, sales and labor cost, respectively, in firms in which it has retained a golden share. The state hence demonstrates socially-oriented tendency in contributing to increasing labor costs.
} 
most beneficial for corporate performance. None of the estimated effects of ownership on the rate of change of profit and only one effect on the change in ROA is timevarying, which contradicts the conjecture that the effect may be U-shaped over time.

In contrast to the significant effects on profit, no initial post-privatization form of ownership has a significant effect on the rate of change of sales revenue except for highly dispersed ownership, which has a large, though marginally significant, positive effect. Similarly, only majority domestic and highly dispersed ownerships have (marginally) significant negative and positive effects on the rate of change of labor cost, relative to majority state ownership, respectively. The effects of all other forms of ownership on sales and labor cost are statistically indistinguishable from that of majority state ownership. Since the effect of majority state ownership on the rate of change of labor cost is U-shaped and the effects of majority domestic and highly dispersed ownerships on labor cost are constant, it follows that one cannot reject the hypothesis that labor cost adjustment in firms of all types of ownership is of the Ushape observed in majority state ownership category. Moreover, since wages in public and private firms moved in tandem during this period (Munich, Svejnar, and Terrell, 2002), a rate of change version of Blanchard's (1997) hypothesis that firms restructure by first lowering and later increasing employment appears to be supported in our data in all categories of ownership.

The results for the initial post-privatization ownership hence indicate that only firms with majority domestic ownership restructure and achieve higher growth rate of profit by reducing their labor cost (defensive restructuring), while only firms with highly dispersed ownership increase their profit growth rate by increasing the rate of growth of sales revenue. ${ }^{34}$ This is a provocative finding because it has been widely

\footnotetext{
${ }^{34}$ These latter firms also increase the rate of growth of their labor cost, but at a lower rate than the increase of sales revenue.
} 
presumed that both domestic and foreign private ownership, especially highly concentrated forms, leads to substantial strategic restructuring and increases in sales -domestically and/or on the world markets. We have checked the sensitivity of these result and we find that they are robust except that majority foreign ownership generates an 11 percent positive effect on sales with additional trimming of about 10 percent of observations with the most extreme values of sales. Other types of owners that achieve higher rates of growth of operating profit without increasing sales revenue or reducing labor cost presumably do so by reducing the rates of increase of non-labor costs and/or generating income from other sources than sales (e.g., rental income, dividends from stock ownership, inter-enterprise credit, and reduction in debt service).

The permanent and contemporaneous effects of changes in ownership that took place during the 1996-99 period are reported in the second and third panel of Table 4, respectively. While there are a number of statistically significant effects, almost all are significant at the 10 percent test level only. Starting with ROA, we see that a switch to majority domestic, majority foreign and blocking minority foreign ownership results in positive permanent ROA effects. The results also show that majority domestic and blocking minority foreign owners tend to acquire firms that perform below average and bring up their profitability in the following years. In terms of rate of change in operating profit, shifts to majority foreign and legal minority state ownership are associated with negative effects, while the few firms that change to highly dispersed ownership register a large positive effect. Since the effects on operating profit reflect relatively small changes near the zero profit level when the corresponding effect on ROA is nil or of the opposite sign, our analysis indicates that the post-privatization changes in ownership have positive effects on profit (measured 
by ROA) at high levels of concentration of domestic private ownership and at high as well as medium levels of concentration of foreign ownership. These results hence also provide support for the agency theory. Finally, three of the six significant effects on the two profit variables are U-shaped and two are inverted U-shaped, indicating that the adjustment in profitability is a dynamic process that varies in its form. There is also an indication that the effects of more concentrated ownership tend to be Ushaped, while those of the more dispersed ownership tend to display an inverted U pattern.

The estimated effects of subsequent ownership on sales and labor cost are virtually all constant rather than U- or inverted U-shaped. The results for sales revenue indicate that there is a positive long-term effect on the rate of change of sales revenue associated with a post 1996 shift to majority foreign ownership and negative effects on sales brought about by a switch to blocking and legal minority state, blocking minority domestic, legal minority foreign, and highly dispersed ownership. Post-privatization shifts to majority foreign ownership hence bring about a rise in sales revenue, while changes toward several types of minority and highly dispersed ownership are associated with reductions in the rate of growth of sales revenue. These findings, as well as the aforementioned ones related to profitability, provide support to the agency theory and contradict theories claiming that dispersed private ownership, giving autonomy to managers, is most beneficial for corporate performance.

The increase in sales brought about by a shift to majority foreign ownership is not accompanied by a parallel increase in labor cost, implying that foreign owners that acquire majority stakes in firms after privatization engage in strategic restructuring that increases sales and standardized profitability. Shifts to blocking minority state and domestic ownership bring about negative effect on both sales and labor cost, 
suggesting that these owners downsize the newly acquired companies. Shifts to legal minority state and foreign ownership, as well as highly dispersed ownership, lead to decreases in the rate of increase of sales revenue. Finally, blocking minority foreign and highly dispersed ownership categories are associated with positive effects on the rate of change of labor cost.

Firms in which the state retains a golden share register an inverted U-shaped and on average positive effect on the change of ROA and operating profit, but also a constant positive effect on the annual rate of increase in labor costs. The two effects suggest that the state induces profit-oriented restructuring but also pursues (at least in part) a social objective of employment generation. Since the state retains golden shares primarily in state-owned and domestic private firms (Table 2), the effect of golden share accentuates the effect of state-owned firms to increase labor cost, and it moderates the tendency of firms with domestic majority and blocking minority ownership to reduce it.

\section{Effects of Different Types of SLOs}

The performance effects of a given owner being or becoming the single largest owner (SLO) of the firm are reported in Table 5. As may be seen from the first panel of the table, the only initial post-privatization ownership that has a positive effect on the change in ROA is that by a foreign industrial company. All five types of domestic non-state SLOs have effects that are not statistically different from that of state SLO, while foreign non-industrial ownership has a small negative $U$ shaped effect. All types of SLOs register a positive 1996 ownership effect on the rate of change of operating profit but, as explained earlier, for domestic industrial companies, banks, investment funds, individuals, and portfolio companies, as well as foreign non- 
industrial firms, this merely means that they register relatively large percentage increases at low levels of profit.

The positive profit effects of the initial foreign industrial company ownership is matched by a positive effect on the rate of change of sales revenue, while the domestic industrial company ownership is associated with a negative effect on the rate of growth of both sales revenue and labor cost. On average, the post-privatization foreign industrial owners thus increase profitability by enhancing the rate of growth of sales without changing the rate of growth of labor cost. Their domestic counterparts do not succeed in raising profitability but they reduce the rate of growth of both sales and labor cost. The former restructuring is of a strategic and the latter of a defensive type. The other type of SLO that engages in significant restructuring is the investment fund that reduced significantly the rate of increase of labor cost and generates a significant increase in the rate of increase of profit but not of standardized profitability.

In contrast to the numerous effects associated with the extent of ownership, post-privatization changes in the type of single largest owner have few effects on profitability. As may be seen from the second and third panel of Table 5, the notable case is a positive long term effect of bank ownership on both measures of profit, offsetting in part the negative contemporaneous (instantaneous) effect associated with the shift to bank ownership. There are two possible explanations for these effects. One is that the banks acquired relatively unprofitable firms and then turned them around. The other interpretation is that at the time of acquisition the banks restructured the firms' finances (e.g., by repaying enterprise loans) and thus temporarily decreased their profits, with a positive effect on both measures of profit being observed in the medium to long term. A symmetrically opposite effect is found with respect to the 
non-industrial foreign owners who register a strong positive instantaneous effect on the rate of change of operating profit together with a corresponding negative effect thereafter. Since there are no corresponding effects on ROA, these large percentage effects are not very important as they occur at low levels of profit or loss. The only other significant effect is a negative effect of investment funds on ROA.

Interestingly, as foreign industrial companies become SLOs in the postprivatization (1996-99) period, they bring about increased rates of growth of both sales and labor cost, thus suggesting that in this phase foreign companies acquire firms to speed up the expansion of production but they no longer hold back the rate of growth of labor cost. In contrast, firms in which a domestic industrial firm becomes the single largest owner in the 1996-99 period continue to reduce the rate of growth in labor costs. Finally, investment funds that become SLOs in the 1996-99 period acquire firms with a high rate of increase in labor cost (panel 3 of Table 5), but they reduce the rate of growth of both labor cost and revenue thereafter (panel 2).

The effect of the state retaining a golden share is similar for the extent of ownership and SLO. As may be seen in Table 5, in the SLO specification the golden share is also associated with an inverted U-shaped increase in the change in ROA and a time-invariant increase in the rate of change of the labor cost. ${ }^{35}$

\section{Concluding Observations}

Compared to other studies of the effect of ownership on performance, our analysis is of interest because we (a) have detailed information on the forms and concentration of ownership in a virtually complete population of medium and large firms privatized in a model large-scale privatization economy, (b) use a four-year

35 Compared to the extent of ownership, the golden share has no effect on the rate of change of operating profit. 
panel of data that come from the post privatization period when one can observe medium-term effects corresponding to strategic restructuring, (c) have data conforming to the international accounting system, and (d) control systematically for potential sample selection bias.

We use the detailed ownership data to estimate the performance effect of ownership along two important dimensions: (i) the degree of concentration of private domestic, private foreign, and state ownership, irrespective of the number of owners within each of these ownership categories and (ii) particular type of owner in terms of eight principal types of single largest owners (SLOs).

Our empirical findings provide the following key insights into the behavior of firms after large-scale privatization:

1. When analyzing firm performance by the extent of ownership, foreign majority owners are found to be the only group that engages in strategic restructuring by increasing profitability and sales revenue (without affecting the rate of change of labor cost) relative to majority state-owned firms. When we classify firms by SLO, the firms that display this behavior are foreign industrial companies.

2. Domestic private owners with relatively concentrated holdings pursue defensive restructuring by reducing labor cost and in some cases also sales revenue, without increasing profit, relative to majority state owned firms.

3. The behavior of all other types of firms is basically indistinguishable from majority state-owned firms, especially in terms of ROA.

4. The above results provide strong support for the prediction of the agency theory that concentrated ownership results in superior performance on account of better monitoring of managers, maximization of shareholder value and availability of external finance. The findings go counter to models that see concentrated ownership 
as being deleterious to firm performance because excessive control stifles managerial initiative and incentives to acquire information in situations of high uncertainty (see e.g., Aghion and Tirole, 1997) or because it results in insufficient liquidity of the company's stock, inadequate information value of the stock market and therefore inferior performance of firms (e.g., Holmstrom and Tirole, 1983). Finally, the lack of a positive profit effect among virtually all types of domestic owners is consistent with Burkart, Gromb and Panunzi's (2000) thesis that the presence of a large (minority) stockholder may not result in a superior performance if this shareholder "loots" the firm at the expense of small shareholders - a phenomenon that has been documented in a number of case studies of firms in the transition economies.

5. When we classify firms by the extent of ownership, we find support for (a rate of change form of) the hypothesis advanced by Blanchard's (1977) that firms restructure by lowering and later increasing employment.

6. By retaining a golden share, the state induces a positive effect on profitability as well as a higher rate of increase of the labor cost. With this indirect form of managerial control, as opposed to ownership, the state hence appears to pursue both restructuring and a social (employment generating) objective. Our analysis hence suggests that the state plays a positive part in stimulating profitable restructuring, while pursuing a socially understandable objective in a period of rising unemployment. Our results hence depict the state in transition economies as a more economically and socially beneficial agent than has been argued in some recent studies.

Overall, our study shows that after large-scale privatization of a completely state-owned economy, foreign ownership leads to superior economic performance relative to domestic private and state ownership. Initial domestic private ownership is 
not superior to state ownership and in some categories (e.g., the most numerous category of ownership by an industrial company) it does not result in significantly higher profit while reducing sales and labor cost. Yet, there are indications that some types of owners display different behavior in their capacity of initial post-privatization owners and subsequent owners. In particular, as initial post-privatization owners, majority domestic private owners reduce labor cost without generating a positive effect on sales or profit. However, as owners that acquire their stake later, majority domestic private owners increase profit without a negative effect on labor cost. The behavior of domestic private owners may hence be evolving over time. On the whole, some of our findings support and some challenge previous findings and beliefs, thus providing evidence that should stimulate further debate. 


\section{References}

Allen, F. and D. Gale. 1995. "A welfare comparison of intermediaries in Germany and the US." European Economic Review, 39(2): 179-209.

Angelucci, M., S. Estrin, J. Konings, and Z. Zólkiewski. 2002. "The Effect of Ownership and Competitive Pressure on Firm Performance in Transition Countries: Micro Evidence from Bulgaria, Romania and Poland", The William Davidson Institute Working Paper No. 434, Ann Arbor, MI.

Aghion, P., and W. Carlin. 1996. Restructuring Outcomes and the Evolution of Ownership Patterns in Central and Eastern Europe. Economics of Transition, 4(2), 371-88.

Aghion, P., and J. Tirole. 1997. "Formal and Real Authority in Organizations", Journal of Political Economy, 55: 1-27.

Ashenfelter, O., and Card, D. 1985. "Using the Longitudinal Structure of Earnings to Estimate the Effect of Training Programs". Review of Economics and Statistics 67(4), 648-60.

Barberis, N., M. Boycko, A. Shleifer and N. Tsukanova. 1996. "How Does Privatization Work? Evidence from the Russian Shops." Journal of Political Economy 104, 764-90.

Barro, Robert J. and Sala-i-Martin, Xavier. 1995. Economic growth. Advanced Series in Economics. New York, London and Montreal: McGraw-Hill.

Bevan, Alan, Saul Estrin and Mark Schaffer. 1999. Determinants of Enterprise Performance during Transition. Centre for Economic Reform and Transformation (CERT) Working Paper 99/03.

Bilsen, V. and J. Konings. 1998. "Job Creation, Job Destruction, and Growth of Newly Established, Privatized, and State-Owned Enterprises in Transition Economies: Survey Evidence from Bulgaria, Hungary, and Romania”, Journal of Comparative Economics, 26 (1998): 429-445

Blanchard, O. 1997. The Economics of Post-Communist Transition. Oxford: Oxford University Press.

Bolton, Patrick, and Ernst-Ludwig von-Thadden. 1998. "Blocks, Liquidity, and Corporate Control". Journal of Finance, 53(1), 1-25.

Bornstein, M. 2001. "Post-privatization enterprise restructuring," Post-Communist Economies 13: (2) 189-203.

Burkart, Michael, Dennis Gromb and Fausto Panunzi, 2000. "Agency Conflict in Public and Negotiated Transfer of Corporate Control." Journal of Finance, 55 (2) 647-677.

Carlin, W., S. Fries, M.E. Schaffer, and P. Seabright. 2001. "Competition and Enterprise Performance in Transition Economies: Evidence from a Crosscountry Survey", CEPR Discussion Paper DP2840, London.

Caves, D.W. and L. Christensen. 1980. "The Relative Efficiency of Public and Private Firms in a Competitive Environment: The Case of Canadian Railroads," Journal of Political Economy, 88 (5), 958-76.

Claessens, S. and S. Djankov. 1999. "Ownership Concentration and Corporate Performance in the Czech Republic." Journal of Comparative Economics 27 498-513.

Coffee, J. 1996. Institutional Investors in Transitional Economies: Lessons from the Czech Experience. In: Frydman, R., Gray, C., and Rapaczynski, A. (eds.): Corporate governance in Central Europe and Russia. Volume 1. Banks, 
funds, and foreign investors. Budapest, Central European University Press 1996, s. 111-86.

Cornelli, F., Portes R., and Schaffer M. E. 1996. The Capital Structure of Firms in Central and Eastern Europe. CEPR Discussion Paper No. 1392.

Demsetz, Heinz and Karl Lehn. 1985. The Structure of Corporate-Ownership - Causes and Consequences. Journal of Political Economy 93: (6) 1155-1177.

Djankov, S. and Murrell, P. 2002. "Enterprise Restructuring in Transition: A Quantitative Survey," Journal of Economic Literature, XL (3) 739-792

Filer, R. K. and J. Hanousek. 2002. "Data Watch: Research Data from Transition Economies." Journal of Economic Perspectives 16, 1, 225-240.

Frydman, R., C.W. Gray, M. Hessel and A. Rapaczynski. 1999. "When does Privatization Work? The Impact of Private Ownership on Corporate Performance in Transition Economies." Quarterly Journal of Economics 114: 1153-91.

Frydman, R., M. Hessel and A. Rapaczynski. 2000. Why Ownership Matters? Entrepreneurship and the Restructuring of Enterprises in Central Europe. C.V. Starr Center for Applied Economics Working Paper, NYU, New York.

Grosfeld, I. and J.F. Nivet. 1997. "Firm's Heterogeneity in Transition: Evidence From a Polish Panel Data Set," William Davidson Institute Working Paper No.47, 1997.

Grosfeld, I. and Roland, G. 1997. "Defensive and Strategic Restructuring in Central European Enterprises." Journal of Transforming Economies and Societies, 3(4): 21-46.

Grosfeld, I. and T. Tressel. 2001. "Competition and Corporate Governance: Substitutes or Complements? Evidence from the Warsaw Stock Exchange," William Davidson Institute WP No. 369.

Gupta, N., J. C. Ham, and J. Svejnar. 2000. Priorities and Sequencing in Privatization: Theory and Evidence from the Czech Republic. William Davidson Institute WP No. 323.

Heckman, J. 1979. "Sample selection bias as a specification error." Econometrica 47: 153-161

Heckman, J., and Hotz, V. 1989. "Choosing among Alternative Nonexperimental Methods for Estimating the Impact of Social Programs: The Case of Manpower Training”. Journal of the American Statistical Association 84(408), 862-74.

Holmström, B., and J. Tirole. 1983. "Market liquidity and performance monitoring”, Journal of Political Economy, 101: 678-709.

Huber, P. J. 1967. The behavior of maximum likelihood estimates under nonstandard conditions. Proceedings of the Fifth Berkeley Symposium on Mathematical Statistics and Probability, 221-223. Berkeley, CA: University of California Press.

Iskander, Magdi R. and Chamlou, Nadereh. 2000. Corporate governance: $A$ framework for implementation. World Bank, Washington, D.C.

Jensen, Michael C. 2000. A theory of the firm: Governance, residual claims, and organizational forms. Cambridge and London: Harvard University Press.

Kočenda, E.: Residual State Property in the Czech Republic. Eastern European Economics, 37, 1999, 5, 6-35.

Kočenda, E., and Valachy, J. 2002. Firm Ownership Structures: Dynamic Development. Prague Economic Papers, 11, 3, 255-268.

Kotrba, J.: Privatization Process in the Czech Republic: Players and Winners, pp. 159198. In Svejnar, J., The Czech Republic and economic transition in Eastern 
Europe. San Diego; London and Toronto: Harcourt Brace, Academic Press, 1995.

Kotrba, J. and J. Svejnar. 1994. Rapid and Multifaceted Privatization: Experience of the Czech and Slovak Republics. Nomisma/Most, 147-185.

Kruskal, W. H. and W.A. Wallis. 1952. Use of ranks in one-criterion variance analysis. Journal of the American Statistical Association 47: 583-621.

Lízal, L. and E. Kočenda. 2001. State of Corruption in Transition: The Case of the Czech Republic. Emerging Markets Review, 2, 2, 138-160.

Lízal, L. and J. Svejnar. 2002. "Investment, Credit Rationing, and the Soft Budget Constraint: Evidence from Czech Panel Data," The Review of Economics and Statistics, 84(2), 353-370.

Megginson, W.L. and Netter J.R. 2001 "From state to market: A survey of empirical studies on privatization", Journal of Economic Literature 39: (2) 321-389, June 2001.

Munich, D., J. Svejnar and K. Terrell. 2002. Returns to Human Capital under the Communist Wage Grid and During the Transition to a Market Economy. The William Davidson Institute Working Paper No. 272.

Pohl, G., R. Anderson, S. Claessens, and S. Djankov. 1997. Privatization and Restructuring in Central and Eastern Europe: Evidence and Policy Options. World Bank Technical Paper No. 368.

Roland, G. Transition and Economics: Politics, Markets and Firms. Cambridge, MA: MIT Press, 2000.

Sachs, Jeffrey, Clifford Zinnes and Yair Eilat. 2000. The Gains from Privatization in Transition Economies: Is Change of Ownership Enough? CAER II Discussion Paper 63, Harvard Institute for International Development, Cambridge, MA.

Shirley, Mary and Patrick Walsh. 2000. Public versus Private Ownership: The Current State of the Debate. The World Bank, Washington, DC, 2000.

Shleifer, A., R. and Vishny. 1997. "A Survey of Corporate Governance," Journal of Finance, 52(2): 737-783.

Smith, S., B. Cin, and M. Vodopivec. 1997. Privatization Incidence, ownership Forms, and Firm Performance: Evidence from Slovenia. Journal of Comparative Economics, 25, 158-179.

Svejnar, J. and M. Singer. 1994. Using Vouchers to Privatize an Economy: The Czech and Slovak Case. Economics of Transition 2, 43-64.

Temple, Jonathan. 1999. The New Growth Evidence. Journal of Economic Literature, 37(1): 112-56.

White, H. 1982. Maximum likelihood estimation of misspecified models. Econometrica 50: 1-25. 
Table 1

Summary Statistics of Performance Indicators: 1996-1999

\begin{tabular}{lcccccc}
\hline \hline & Mean & Std. Dev. & Min & Max & No. Firms & No.Obs. \\
\hline $\begin{array}{l}\text { Change in ROA } \\
\text { Rate of Growth of }\end{array}$ & 0.001 & 0.098 & -0.393 & 0.387 & 1540 & 2905 \\
$\quad$ & & & & & & \\
Operating Profit & 0.109 & 1.023 & -2.995 & 2.998 & 1497 & 2529 \\
Sales & 0.009 & 0.426 & -1.000 & 2.820 & 1371 & 2592 \\
$\quad$ Labor Costs & 0.010 & 0.364 & -1.000 & 2.842 & 1539 & 2949 \\
\hline \hline
\end{tabular}

The ratio of the number of observations to number of firms varies due to an unbalanced nature of the panel. Change in ROA is defined as a ratio of change in profits between two consecutive periods to total assets at the beginning period. Formally: [(Profit(t)-Profit(t-1))/Total Assets(t-1)]. 
Table 2

Ownership Extent and Categories: Summary Statistics

Panel A: Ownership Extent

\begin{tabular}{lccccccc}
\hline & & & \multicolumn{5}{c}{ Number of observations } \\
\cline { 3 - 8 } $\begin{array}{l}\text { Type of aggregate } \\
\text { ownership }\end{array}$ & $\begin{array}{c}\text { Num. of } \\
\text { obs. }\end{array}$ & $\begin{array}{c}\text { Mean size } \\
\text { of stake (\%) }\end{array}$ & $\begin{array}{c}\text { Majority } \\
\text { held by SLO }\end{array}$ & $\begin{array}{c}\text { Blocking Minority } \\
\text { held by SLO }\end{array}$ & $\begin{array}{c}\text { Legal Minority } \\
\text { (Moderately } \\
\text { Dispersed } \\
\text { Ownership) }\end{array}$ & $\begin{array}{c}\text { Other (Highly } \\
\text { Dispersed } \\
\text { Ownership) }\end{array}$ & $\begin{array}{c}\text { Golden } \\
\text { Share held } \\
\text { by State }\end{array}$ \\
\hline Domestic & 2115 & 44.84 & 758 & 679 & 656 & 22 & 80 \\
Foreign & 303 & 57.14 & 165 & 86 & 45 & 7 & 9 \\
State & 174 & 43.18 & 49 & 63 & 58 & 4 & 66 \\
\hline Total & 2592 & 46.16 & 972 & 828 & 759 & 33 & 155 \\
\hline
\end{tabular}

Panel B: Type of Ownership by Single Largest Owner (SLO)

\begin{tabular}{|c|c|c|c|c|c|c|c|}
\hline \multirow[b]{2}{*}{$\begin{array}{l}\text { Type of single } \\
\text { largest owner } \\
\text { (SLO) }\end{array}$} & \multirow[b]{2}{*}{$\begin{array}{l}\text { Num. of } \\
\text { obs. }\end{array}$} & \multirow[b]{2}{*}{$\begin{array}{c}\text { Mean size } \\
\text { of stake (\%) }\end{array}$} & \multicolumn{5}{|c|}{ Number of Observations } \\
\hline & & & $\begin{array}{c}\text { Majority } \\
\text { held by SLO }\end{array}$ & $\begin{array}{l}\text { Blocking Minority } \\
\text { held by SLO }\end{array}$ & $\begin{array}{c}\text { Legal Minority } \\
\text { (Moderately } \\
\text { Dispersed } \\
\text { Ownership) }\end{array}$ & $\begin{array}{l}\text { Other (Highly } \\
\text { Dispersed } \\
\text { Ownership) }\end{array}$ & $\begin{array}{l}\text { Golden } \\
\text { Share held } \\
\text { by State }\end{array}$ \\
\hline \multicolumn{8}{|c|}{ Domestic Ownership } \\
\hline Industrial Co. & 1244 & 48.83 & 547 & 412 & 272 & 13 & 42 \\
\hline Bank & 33 & 46.42 & 11 & 14 & 7 & 1 & 1 \\
\hline Invest. Fund & 423 & 37.61 & 96 & 119 & 205 & 3 & 19 \\
\hline Individual & 335 & 38.92 & 82 & 99 & 150 & 4 & 13 \\
\hline Portfolio Co. & 80 & 45.06 & 22 & 35 & 22 & 1 & 5 \\
\hline State & 174 & 43.18 & 49 & 63 & 58 & 4 & 66 \\
\hline \multicolumn{8}{|c|}{ Foreign Ownership } \\
\hline Industrial Co. & 236 & 58.81 & 139 & 60 & 30 & 7 & 6 \\
\hline Others & 67 & 51.23 & 26 & 26 & 15 & 0 & 3 \\
\hline Total & 2592 & 46.16 & 972 & 828 & 759 & 33 & 155 \\
\hline
\end{tabular}

Note: Table contains basic ownership statistics associated with the performance variable of sales. Statistics for other performance indicators are similar. Ownership concentration categories include majority (more than $50 \%$ of shares), blocking minority (from more than 33 to $50 \%$ of shares), legal minority (at least $10 \%$ but not more than $33 \%$ of shares), and other (less than $10 \%$ of shares). All ownership categories are mutually exclusive. Golden share is an additional measure that is not associated with any particular extent of ownership. 
Table 3

Movement of Firms across Ownership Categories: 1996-1999

Panel A: Extent of State, Private Domestic and Foreign Ownership

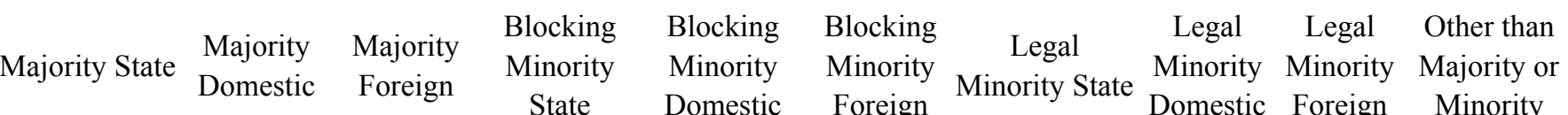

\begin{tabular}{|c|c|c|c|c|c|c|c|c|c|c|c|}
\hline Majority State & $46 \%$ & $29 \%$ & $5 \%$ & $2 \%$ & $11 \%$ & $4 \%$ & $0 \%$ & $2 \%$ & $0 \%$ & $0 \%$ & $100 \%$ \\
\hline Majority Domestic & $0 \%$ & $68 \%$ & $6 \%$ & $0 \%$ & $19 \%$ & $1 \%$ & $0 \%$ & $4 \%$ & $1 \%$ & $0 \%$ & $100 \%$ \\
\hline Majority Foreign & $0 \%$ & $13 \%$ & $73 \%$ & $0 \%$ & $4 \%$ & $9 \%$ & $0 \%$ & $1 \%$ & $1 \%$ & $0 \%$ & $100 \%$ \\
\hline Blocking Minority State & $1 \%$ & $21 \%$ & $5 \%$ & $15 \%$ & $34 \%$ & $3 \%$ & $2 \%$ & $9 \%$ & $3 \%$ & $6 \%$ & $100 \%$ \\
\hline Blocking Minority Domestic & $0 \%$ & $41 \%$ & $3 \%$ & $1 \%$ & $37 \%$ & $3 \%$ & $1 \%$ & $12 \%$ & $1 \%$ & $0 \%$ & $100 \%$ \\
\hline Blocking Minority Foreign & $0 \%$ & $21 \%$ & $19 \%$ & $0 \%$ & $21 \%$ & $35 \%$ & $0 \%$ & $2 \%$ & $2 \%$ & $0 \%$ & $100 \%$ \\
\hline Legal Minority State & $1 \%$ & $24 \%$ & $2 \%$ & $1 \%$ & $27 \%$ & $2 \%$ & $24 \%$ & $18 \%$ & $1 \%$ & $1 \%$ & $100 \%$ \\
\hline Legal Minority Domestic & $0 \%$ & $28 \%$ & $2 \%$ & $1 \%$ & $34 \%$ & $2 \%$ & $1 \%$ & $30 \%$ & $1 \%$ & $0 \%$ & $100 \%$ \\
\hline Legal Minority Foreign & $0 \%$ & $13 \%$ & $18 \%$ & $0 \%$ & $17 \%$ & $15 \%$ & $0 \%$ & $14 \%$ & $22 \%$ & $0 \%$ & $100 \%$ \\
\hline Other than Majority or Minority & $0 \%$ & $20 \%$ & $5 \%$ & $0 \%$ & $19 \%$ & $4 \%$ & $3 \%$ & $28 \%$ & $3 \%$ & $17 \%$ & $100 \%$ \\
\hline
\end{tabular}

\begin{tabular}{|c|c|c|c|c|c|c|c|c|c|}
\hline & $\begin{array}{l}\text { Dom. } \\
\text { Industrial Co. }\end{array}$ & $\begin{array}{l}\text { Dom. } \\
\text { Bank }\end{array}$ & $\begin{array}{l}\text { Dom. } \\
\text { Invest. Fund }\end{array}$ & $\begin{array}{l}\text { Dom. } \\
\text { Individual }\end{array}$ & $\begin{array}{l}\text { Dom. } \\
\text { Portfolio Co. }\end{array}$ & State & $\begin{array}{l}\text { For. Industrial } \\
\text { Co. }\end{array}$ & $\begin{array}{l}\text { For. } \\
\text { Other }\end{array}$ & Total \\
\hline Dom. Industrial Co. & $69 \%$ & $1 \%$ & $11 \%$ & $10 \%$ & $2 \%$ & $1 \%$ & $6 \%$ & $1 \%$ & $100 \%$ \\
\hline Dom. Bank & $47 \%$ & $5 \%$ & $25 \%$ & $8 \%$ & $1 \%$ & $1 \%$ & $12 \%$ & $2 \%$ & $100 \%$ \\
\hline Dom. Invest. Fund & $50 \%$ & $4 \%$ & $28 \%$ & $9 \%$ & $2 \%$ & $2 \%$ & $4 \%$ & $1 \%$ & $100 \%$ \\
\hline Dom. Individual & $39 \%$ & $1 \%$ & $9 \%$ & $43 \%$ & $1 \%$ & $1 \%$ & $6 \%$ & $1 \%$ & $100 \%$ \\
\hline Dom. Portfolio Co. & $56 \%$ & $2 \%$ & $18 \%$ & $14 \%$ & $2 \%$ & $2 \%$ & $5 \%$ & $1 \%$ & $100 \%$ \\
\hline State & $47 \%$ & $1 \%$ & $8 \%$ & $9 \%$ & $1 \%$ & $26 \%$ & $7 \%$ & $1 \%$ & $100 \%$ \\
\hline For. Industrial Co. & $15 \%$ & $0 \%$ & $1 \%$ & $3 \%$ & $1 \%$ & $0 \%$ & $75 \%$ & $5 \%$ & $100 \%$ \\
\hline For. Other & $35 \%$ & $1 \%$ & $8 \%$ & $15 \%$ & $1 \%$ & $0 \%$ & $33 \%$ & $8 \%$ & $100 \%$ \\
\hline
\end{tabular}

Panel B: Type of Ownership by the Single Largest Owner (SLO) 
William Davidson Institute Working Paper 471a

Table 4

Effect of Ownership Extent on Performance

(P-values in parentheses)

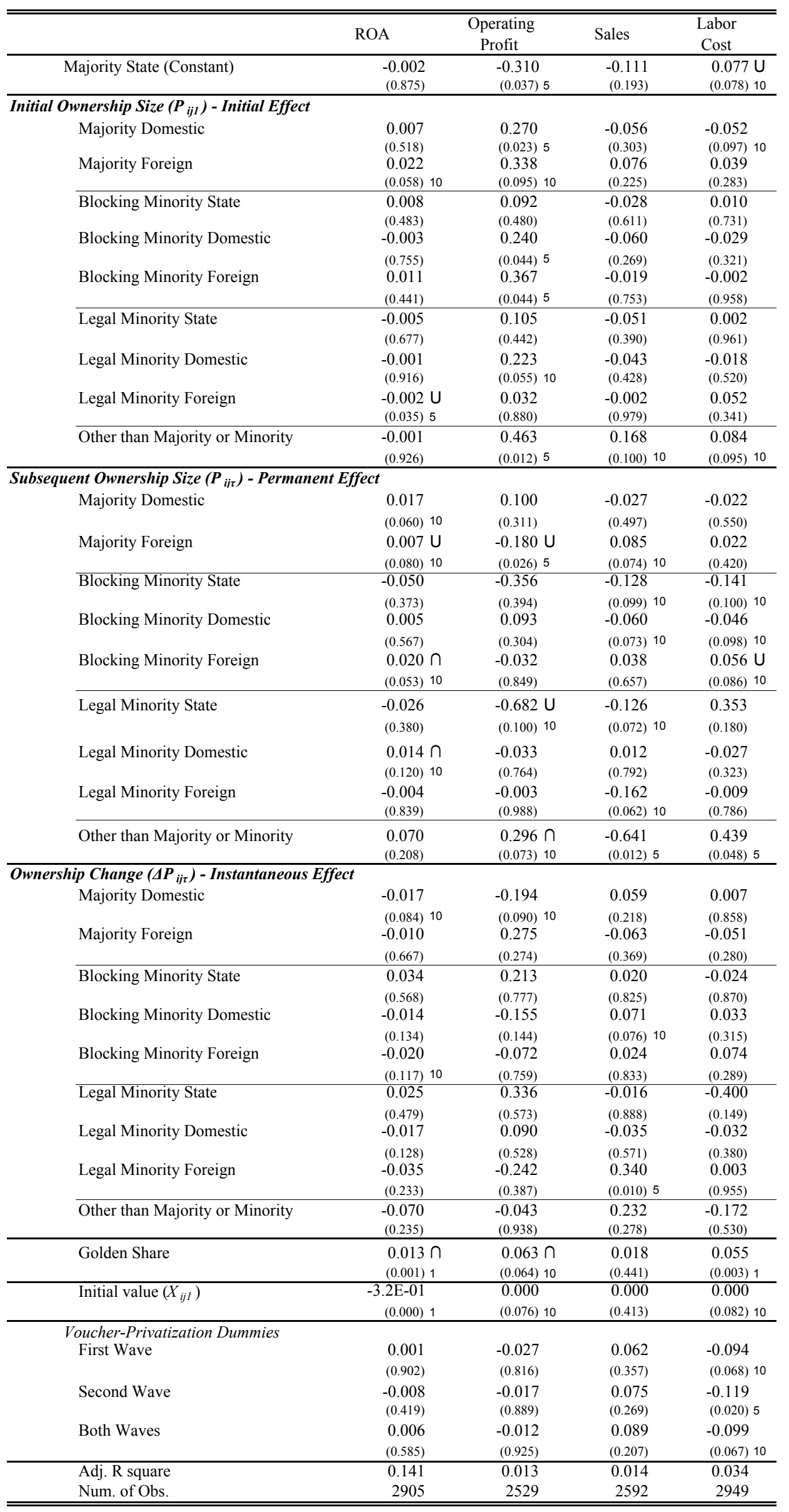

Note: The dependent variables are the change in ROA and the rate of change of operating profit, sales revenue and labor cost, respectively. Numbers in parenthesis are p-values. 1,5 and 10 denote significance at $1 \%, 5 \%$ and $10 \%$ level, two-tail test, respectively. Industry, privatization, and year dummies included. Symbol U denotes U-shape effect over time (convex function). Symbol $\cap$ denotes inverse $U$-shape effect over time (concave function). 
William Davidson Institute Working Paper 471a

Table 5

Effect of the Single Largest Owner (SLO) Type on Performance

(P-values in parentheses)

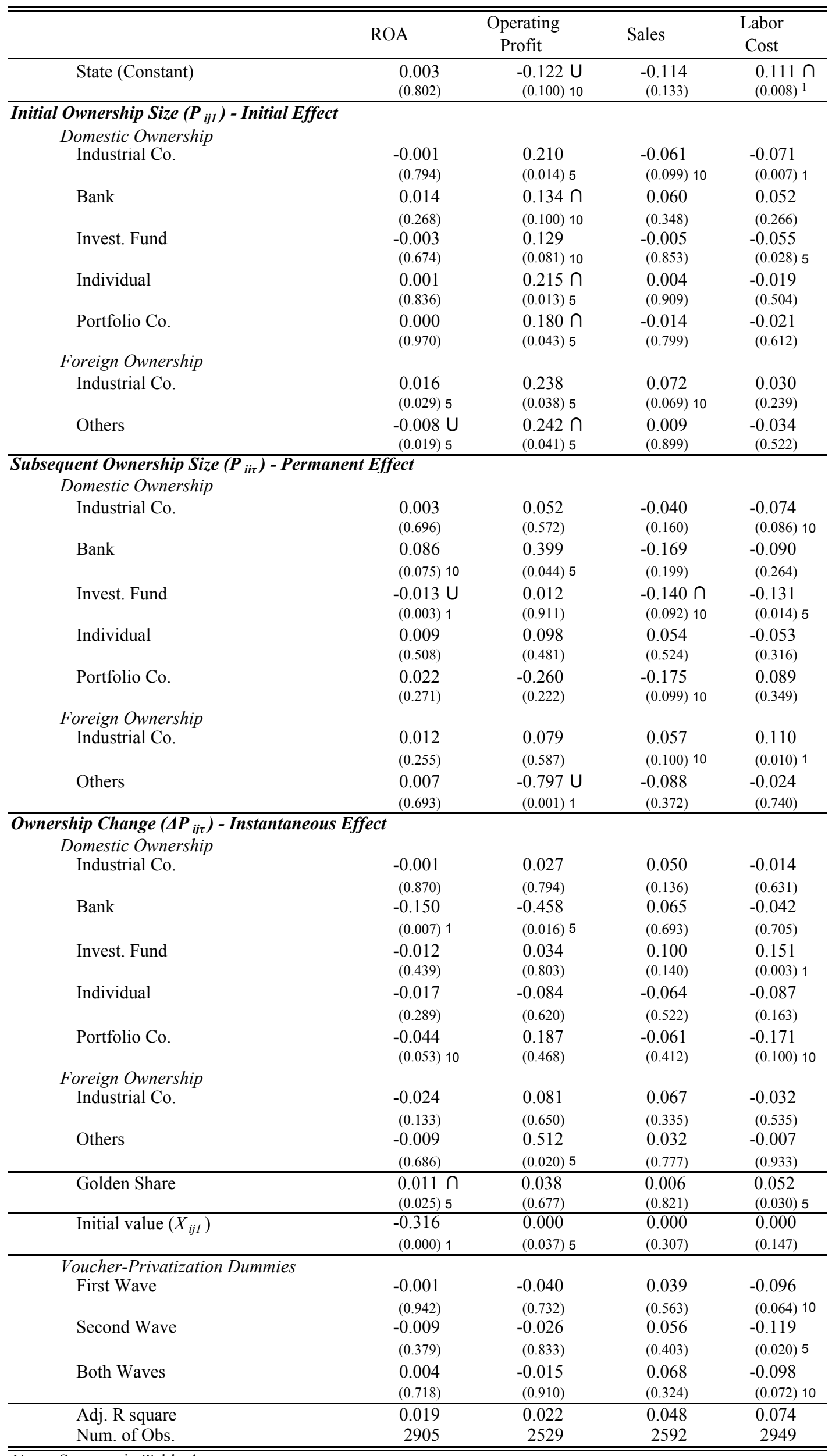

Note: Same as in Table 4. 
William Davidson Institute Working Paper 471a

Table A1

Summary Statistics of Performance Indicators by Ownership Type of SLO: 1996-1999

Mean Std. Dev. Min Max Num. Firms Num. Obs

\begin{tabular}{|c|c|c|c|c|c|c|c|}
\hline \multicolumn{8}{|c|}{ Domestic Ownership } \\
\hline \multirow[t]{4}{*}{ Industrial Co. } & ROA & 0.002 & 0.100 & -0.393 & 0.386 & 852 & 1389 \\
\hline & Operating Profit & 0.138 & 1.042 & -2.987 & 2.998 & 806 & 1205 \\
\hline & Sales & -0.009 & 0.418 & -1.000 & 2.431 & 766 & 1244 \\
\hline & Labor Costs & -0.014 & 0.353 & -1.000 & 2.732 & 860 & 1410 \\
\hline \multirow[t]{4}{*}{ Bank } & ROA & 0.008 & 0.121 & -0.377 & 0.373 & 40 & 45 \\
\hline & Operating Profit & 0.031 & 0.590 & -2.213 & 1.027 & 41 & 45 \\
\hline & Sales & 0.101 & 0.720 & -1.000 & 2.820 & 29 & 33 \\
\hline & Labor Costs & 0.083 & 0.453 & -0.782 & 1.876 & 39 & 43 \\
\hline \multirow[t]{4}{*}{ Invest. Fund } & ROA & 0.006 & 0.109 & -0.369 & 0.387 & 332 & 474 \\
\hline & Operating Profit & 0.138 & 1.053 & -2.978 & 2.957 & 306 & 407 \\
\hline & Sales & 0.016 & 0.444 & -1.000 & 2.726 & 297 & 423 \\
\hline & Labor Costs & 0.024 & 0.401 & -1.000 & 2.842 & 338 & 488 \\
\hline \multirow[t]{4}{*}{ Individual } & ROA & -0.001 & 0.102 & -0.385 & 0.387 & 258 & 380 \\
\hline & Operating Profit & 0.102 & 1.046 & -2.995 & 2.925 & 231 & 320 \\
\hline & Sales & 0.016 & 0.522 & -1.000 & 2.691 & 224 & 335 \\
\hline & Labor Costs & -0.015 & 0.398 & -1.000 & 2.248 & 252 & 379 \\
\hline \multirow[t]{4}{*}{ Portfolio Co. } & ROA & -0.017 & 0.105 & -0.349 & 0.367 & 88 & 98 \\
\hline & Operating Profit & 0.051 & 1.230 & -2.698 & 2.878 & 77 & 89 \\
\hline & Sales & -0.134 & 0.365 & -1.000 & 0.987 & 72 & 80 \\
\hline & Labor Costs & -0.008 & 0.496 & -1.000 & 2.750 & 88 & 100 \\
\hline \multirow[t]{4}{*}{ State } & ROA & -0.006 & 0.052 & -0.250 & 0.164 & 125 & 178 \\
\hline & Operating Profit & -0.050 & 0.785 & -2.844 & 2.580 & 120 & 162 \\
\hline & Sales & 0.026 & 0.217 & -0.994 & 1.325 & 122 & 174 \\
\hline & Labor Costs & 0.081 & 0.238 & -0.989 & 2.219 & 128 & 183 \\
\hline \multicolumn{8}{|c|}{ Foreign Ownership } \\
\hline \multirow[t]{4}{*}{ Industrial Co. } & ROA & -0.001 & 0.077 & -0.298 & 0.235 & 154 & 259 \\
\hline & Operating Profit & 0.113 & 0.884 & -2.860 & 2.791 & 143 & 230 \\
\hline & Sales & 0.105 & 0.380 & -1.000 & 2.795 & 140 & 236 \\
\hline & Labor Costs & 0.091 & 0.284 & -1.000 & 1.643 & 157 & 265 \\
\hline \multirow[t]{4}{*}{ Others } & ROA & -0.006 & 0.094 & -0.368 & 0.257 & 68 & 82 \\
\hline & Operating Profit & -0.066 & 1.205 & -2.916 & 2.962 & 61 & 71 \\
\hline & Sales & -0.004 & 0.290 & -0.902 & 0.868 & 57 & 67 \\
\hline & Labor Costs & 0.033 & 0.333 & -0.800 & 1.613 & 68 & 81 \\
\hline
\end{tabular}

Note: The variables are the change in ROA and the rate of change of operating profit, sales revenue and labor cost, respectively. SLO refers to the Single Largest Owner. 
Table A2

Summary Statistics of Performance Indicators by Extent of Ownership: 1996-1999

\begin{tabular}{|c|c|c|c|c|c|c|c|}
\hline & & Mean & Std. Dev. & Min & Max & Num. Firms & Num.Obs \\
\hline \multirow[t]{4}{*}{ Majority State } & ROA & -0.013 & 0.046 & -0.154 & 0.098 & 34 & 46 \\
\hline & Operating Profit & -0.181 & 0.770 & -2.084 & 1.265 & 34 & 43 \\
\hline & Sales & 0.017 & 0.235 & -0.880 & 0.567 & 35 & 49 \\
\hline & Labor Costs & 0.073 & 0.180 & -0.742 & 0.541 & 36 & 50 \\
\hline \multirow[t]{4}{*}{ Majority Domestic } & ROA & 0.006 & 0.101 & -0.385 & 0.386 & 554 & 870 \\
\hline & Operating Profit & 0.111 & 1.014 & -2.977 & 2.998 & 524 & 768 \\
\hline & Sales & -0.005 & 0.431 & -1.000 & 2.820 & 480 & 758 \\
\hline & Labor Costs & -0.014 & 0.406 & -1.000 & 2.732 & 553 & 880 \\
\hline \multirow{4}{*}{ Majority Foreign } & ROA & 0.002 & 0.084 & -0.298 & 0.257 & 111 & 185 \\
\hline & Operating Profit & 0.089 & 0.953 & -2.732 & 2.932 & 103 & 163 \\
\hline & Sales & 0.089 & 0.360 & -1.000 & 1.707 & 99 & 165 \\
\hline & Labor Costs & 0.057 & 0.285 & -1.000 & 1.643 & 113 & 188 \\
\hline \multirow[t]{4}{*}{ Blocking Minority State } & ROA & -0.003 & 0.049 & -0.250 & 0.164 & 50 & 67 \\
\hline & Operating Profit & 0.034 & 0.741 & -2.281 & 2.580 & 47 & 61 \\
\hline & Sales & 0.015 & 0.140 & -0.552 & 0.291 & 48 & 63 \\
\hline & Labor Costs & 0.077 & 0.155 & -0.682 & 0.641 & 50 & 67 \\
\hline \multirow[t]{4}{*}{ Blocking Minority Domestic } & ROA & -0.004 & 0.099 & -0.367 & 0.387 & 531 & 748 \\
\hline & Operating Profit & 0.101 & 1.046 & -2.987 & 2.884 & 467 & 616 \\
\hline & Sales & -0.005 & 0.441 & -1.000 & 2.405 & 478 & 679 \\
\hline & Labor Costs & -0.021 & 0.339 & -1.000 & 2.842 & 527 & 754 \\
\hline \multirow[t]{4}{*}{ Blocking Minority Foreign } & ROA & -0.001 & 0.063 & -0.248 & 0.226 & 67 & 97 \\
\hline & Operating Profit & 0.137 & 1.024 & -2.916 & 2.962 & 63 & 88 \\
\hline & Sales & 0.055 & 0.413 & -0.929 & 2.795 & 58 & 86 \\
\hline & Labor Costs & 0.094 & 0.319 & -0.765 & 1.568 & 68 & 100 \\
\hline \multirow[t]{4}{*}{ Legal Minority State } & ROA & -0.005 & 0.060 & -0.231 & 0.151 & 40 & 60 \\
\hline & Operating Profit & -0.043 & 0.866 & -2.844 & 1.716 & 38 & 54 \\
\hline & Sales & 0.047 & 0.273 & -0.994 & 1.325 & 39 & 58 \\
\hline & Labor Costs & 0.094 & 0.343 & -0.989 & 2.219 & 41 & 61 \\
\hline \multirow[t]{4}{*}{ Legal Minority Domestic } & ROA & 0.001 & 0.108 & -0.393 & 0.387 & 483 & 743 \\
\hline & Operating Profit & 0.161 & 1.091 & -2.995 & 2.980 & 463 & 657 \\
\hline & Sales & 0.005 & 0.471 & -1.000 & 2.726 & 437 & 656 \\
\hline & Labor Costs & 0.018 & 0.380 & -1.000 & 2.750 & 491 & 759 \\
\hline \multirow[t]{4}{*}{ Legal Minority Foreign } & ROA & -0.024 & 0.095 & -0.368 & 0.102 & 34 & 50 \\
\hline & Operating Profit & -0.154 & 0.984 & -2.860 & 2.596 & 30 & 41 \\
\hline & Sales & 0.102 & 0.310 & -0.469 & 0.917 & 32 & 45 \\
\hline & Labor Costs & 0.090 & 0.276 & -0.558 & 1.613 & 34 & 49 \\
\hline \multirow[t]{4}{*}{ Other than Majority or Minority } & $\mathrm{ROA}$ & 0.015 & 0.088 & -0.248 & 0.245 & 31 & 39 \\
\hline & Operating Profit & 0.242 & 0.649 & -0.909 & 1.680 & 31 & 38 \\
\hline & Sales & -0.059 & 0.301 & -1.000 & 0.283 & 25 & 33 \\
\hline & Labor Costs & 0.149 & 0.398 & -0.463 & 2.073 & 31 & 41 \\
\hline
\end{tabular}

Note: The variables are the change in ROA and the rate of change of operating profit, sales revenue and labor cost, respectively. 


\section{DAVIDSON INSTITUTE WORKING PAPER SERIES - Most Recent Papers}

The entire Working Paper Series may be downloaded free of charge at: www.wdi.bus.umich.edu

CURRENT AS 6/4/02

\begin{tabular}{|c|c|c|}
\hline Publication & Authors & Date \\
\hline $\begin{array}{l}\text { No. 471a: The Effects of Ownership Forms and Concentration on Firm } \\
\text { Performance after Large-Scale Privatization }\end{array}$ & Evzen Kocenda and Jan Svejnar & Jan. 2003 \\
\hline $\begin{array}{l}\text { No. 470: Growth in Transition: What We Know, What We Don't, and } \\
\text { What We Should }\end{array}$ & $\begin{array}{l}\text { Nauro F. Campos and Fabrizio } \\
\text { Coricelli }\end{array}$ & Feb. 2002 \\
\hline $\begin{array}{l}\text { No. 469: Barriers to Investment by Russian Firms: Property Protection } \\
\text { or Credit Constraints? }\end{array}$ & Susan J. Linz & May 2002 \\
\hline No. 468: Job Satisfaction Among Russian Workers & Susan J. Linz & May 2002 \\
\hline $\begin{array}{l}\text { No. 467: Assessing the Problem of Human Capital Mismatch in } \\
\text { Transition Economies }\end{array}$ & $\begin{array}{l}\text { Viliam Druska, Byeong ju Jeong, } \\
\text { Michal Kejak, and Viatcheslav } \\
\text { Vinogradov }\end{array}$ & Mar. 2002 \\
\hline $\begin{array}{l}\text { No. 466: Motivating Russian Workers: Analysis of Age and Gender } \\
\text { Differences }\end{array}$ & Susan J. Linz & Feb. 2002 \\
\hline No. 465: Virtual Reality: Barter and Restructuring in Russian Industry & Gary Krueger and Susan J. Linz & Apr. 2001 \\
\hline $\begin{array}{l}\text { No. 464: Lending of Last Resort, Moral Hazard and Twin Crises: } \\
\text { Lessons from the Bulgarian Financial Crisis 1996/1997 }\end{array}$ & $\begin{array}{l}\text { Michael Berlemann, Kalin } \\
\text { Hristov and Nikolay Nenovsky }\end{array}$ & May 2002 \\
\hline $\begin{array}{l}\text { No. 463: Deindustrialisation. Lessons from the Structural Outcomes of } \\
\text { Post-Communist Transition }\end{array}$ & $\begin{array}{l}\text { Tomasz Mickiewicz and Anna } \\
\text { Zalewska }\end{array}$ & Jan. 2002 \\
\hline $\begin{array}{l}\text { No. 462: Joint Liability Lending and the Rise and Fall of China's } \\
\text { Township and Village Enterprises }\end{array}$ & Albert Park and Minggao Shen & July 2001 \\
\hline $\begin{array}{l}\text { No. 461: A Refinancing Model of Decentralization with Empirical } \\
\text { Evidence from China }\end{array}$ & Albert Park and Minggao Shen & Apr. 2002 \\
\hline $\begin{array}{l}\text { No. 460: The Effects of Market Liberalization on the Relative Earnings } \\
\text { of Chinese Women }\end{array}$ & $\begin{array}{l}\text { Margaret Maurer-Fazio and } \\
\text { James Hughes }\end{array}$ & Mar. 2002 \\
\hline $\begin{array}{l}\text { No. 459: The Role of Education in Determining Labor Market } \\
\text { Outcomes in Urban China's Transitional Labor Markets }\end{array}$ & Margaret Maurer-Fazio & Apr. 2002 \\
\hline $\begin{array}{l}\text { No. 458: Real and Monetary Convergence within the European Union } \\
\text { and Between the European Union and Candidate Countries: } \\
\text { A Rolling Cointegration Approach }\end{array}$ & $\begin{array}{l}\text { Josef C. Brada, Ali M. Kutan and } \\
\text { Su Zhou }\end{array}$ & Apr. 2002 \\
\hline No. 457: Credit Ratings as Coordination Mechanisms & $\begin{array}{l}\text { Arnoud W. A. Boot and Todd T. } \\
\text { Milbourn }\end{array}$ & Mar. 2002 \\
\hline $\begin{array}{l}\text { No. 456: Balkan and Mediterranean Candidates for European Union } \\
\text { Membership: The Convergence of their Monetary Policy with that of the } \\
\text { European Central Bank }\end{array}$ & Josef C. Brada and Ali M. Kutan & Apr. 2002 \\
\hline $\begin{array}{l}\text { No. 455: Russian Financial Transition: The Development of Institutions } \\
\text { and Markets for Growth }\end{array}$ & David M. Kemme & Oct. 2001 \\
\hline $\begin{array}{l}\text { No. 454: Does the Market Pay Off? Earnings Inequality and Returns to } \\
\text { Education in Urban China }\end{array}$ & Xiaogang $\mathrm{Wu}$ and $\mathrm{Yu} \mathrm{Xie}$ & Apr. 2002 \\
\hline $\begin{array}{l}\text { No. 453: Entrepreneurs' Access to Private Equity in China: } \\
\text { The Role of Social Capital }\end{array}$ & Bat Batjargal and Mannie M. Liu & Apr. 2002 \\
\hline $\begin{array}{l}\text { No. 452: The Determinants of Privatised Enterprise Performance in } \\
\text { Russia }\end{array}$ & $\begin{array}{l}\text { Alan A. Bevan, Saul Estrin, Boris } \\
\text { Kuznetsov, Mark E. Schaffer, } \\
\text { Manuela Angelucci, Julian } \\
\text { Fennema and Giovanni } \\
\text { Mangiarotti }\end{array}$ & June 2001 \\
\hline $\begin{array}{l}\text { No. 451: Determinants of Financial Distress: What Drives Bankruptcy } \\
\text { in a Transition Economy? The Czech Republic Case }\end{array}$ & Lubomír Lízal & Jan. 2002 \\
\hline No. 450: Corporate Governance and the Global Social Void & Lee A. Tavis & Oct. 2001 \\
\hline $\begin{array}{l}\text { No. 449: Financial Architecture and Economic Performance: } \\
\text { International Evidence }\end{array}$ & Solomon Tadesse & Aug. 2001 \\
\hline $\begin{array}{l}\text { No. 448: Growth Slowdown Under Central Planning: A Model of Poc } \\
\text { Incentives }\end{array}$ & Zuzana Brixiová and Aleš Bulír & Mar. 2002 \\
\hline
\end{tabular}

